\title{
住民による「運動の場づくり」が地域全体の高齢者の運動習慣に与える効果 ーポピュレーションアプローチによる「運動格差」縮小に挑む一
}

\author{
甲 斐 裕子
}

(公益財団法人明治安田厚生事業団体力医学研究所)

\section{1. ポピュレーションアプローチと運動格差}

我が国における運動習慣をめぐる課題は，運動習慣者 が増えないということだけではない，社会経済的要因に よって運動習慣者の割合に違いがある「運動格差」も社 会的課題のひとつである。例えば，所得が少ないほど運 動習慣者が少ないことが知られている。一方, ポピュレー ションアプローチは有用である半面，格差を広げる可能 性が指摘されている1)。つまり, やり方次第では, 社会 経済的に恵まれた健康意識の高い層はますます健康にな る一方で, 社会経済的弱者が置き去りにされるという懸

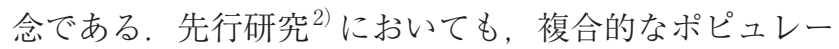
ションアプローチを行ったところ, 高学歴グループのみ で歩数が増加したことが報告されている. 現場でも「何 を企画しても健康意識の高い同じ人しかこない」「本当 に来て欲しい人が参加しない」等は, 自治体の共通の悩 みである。すなわち, 運動・身体活動促進には, 格差に 配慮したアプローチが必要である.

\section{2. 瀬谷スタディの概要}

地域全体の高齢者の運動習慣者の増加を目的に, 筆者 らは横浜市瀬谷区と協力して2009年に「瀬谷スタデイ」3) を開始した，高齢者が運動できない理由として，運動 する場所・機会・仲間の不足が報告されている ${ }^{4)}$. なら ば，住民同士で運営する「運動の場」を地域に数多くつ くることが, 効果的なポピュレーションアプローチにな るのではないかという仮説を立てた，介入地区と対照地 区を設け，介入地区では住民から運動支援ボランティア を養成した，さらに，各地域で自主グループ活動を実施 してもらうとともに，その活動を支援した，評価は，1 年ごとの連続横断調査とし，60～84歳の男女を無作為抽 出して郵送調查を行った。主要評価項目は週 2 回以上 の運動習慣者の割合とした。さらに暮らし向きも調査 し, 運動格差への影響を確認した。 介入は 2 年間行い, 介入終了から 3 年後に追跡調査を実施した。本稿では, PAIREMの枠組みに沿って報告する。

3.PAIREMによる評価

(1) P 計画 目標：身近な場所（徒歩10分園内）で「運動 の場づくり」を実施

範囲とターゲット：積極的に支援するのは介 入地区のみ

(2)A採用 行政区：介入地区で採用 (100\%)

組織：自治会, 社協, 地域ケアプラザ等と連携

(3) I 実施 情報提供：区報, 回覧板, 社協の広報等 教育機会：運動支援ボランティア講習会（1 回 4 日間 $\times 3$ 回）

サポート環境：区保健師と研究者が随時相談

\section{に対応}

(4) R 到達 認知の割合 : 活動の認知率 $31 \%$ 行動の割合：「運動の場」に参加したことが ある者 $5.5 \%$

(5) E 効果 設定した場：7 か所 運動実践者：介入地区全体 $+4.8 \%$ （暮らし向 きが苦しい層 $+7.5 \%)$

(6)M継続 採用の継続： 1 地区 (100\%)，7 ケ所ともに 活動を継続

運動実践者：- $3 \%$

\section{4.まとめ}

運動の場づくりによって地域全体の高齢者の運動習慣 者が増加した。特に, 社会経済的地位の低い層の運動習 慣者が増加することが確認された。これからの結果か ら, 運動の場づくりというポピュレーションアプローチ は, 格差を拡大させることなく, 運動習慣者を増やすこ とが示唆された。運動支援ボランティア養成講座では, 「自主グループ活動に積極的に声掛けするのはどんな人 か?」について考える機会を設けてきた。これが結果と して傾斜をつけたユニバーサル・アプローチ怆になった 可能性がある.

また, PAIREMで評価することで，プロセスを見える 化するとともに，他の取り組みと比較することが可能に なった，さらに，活動は継続しているものの先細りしてお り, 継続的支援が必要であることも浮かび上がってきた。

住民による運動の場づくりは, 新しい手法ではない. 住民ボランティア育成や運動サークル支援ととらえれば, 地域保健では古典的であり，すでに多くの自治体で実施 されている，そのため普及しやすい手法ともいえる，運 動の場づくりを格差に配慮し戦略的に実施することで, 格差を縮小させつつ運動習慣者を増やせる可能性がある。

\section{【文献】}

1. 福田吉治. ポピュレーションアプローチは健康格差を拡 大させる? vulnerable population approachの提言. 日本 衛生学雑誌. 2008; 63: 735-738.

2. De Cocker KA, De Bourdeaudhuij IM, Brown WJ, et al. Four-year follow-up of the community intervention '10,000 steps Ghent'. Health Educ Res. 2011; 26: 372-380.

3. 甲斐裕子. 地域に㧍ける健康づくり集団戦略の実践とそ の評価一身体活動の促進を目指して一. 日本健康教育学 会誌. 2018; 26: 54-58.

4. 重松良祐, 中垣内真樹, 岩井浩一, 他. 運動実践の頻度別に みた高齢者の特徵と運動継続に向けた課題. 体育学研究. 2007; 52: 173-86.

5. 近藤尚己. 健康格差対策の進め方一効果をもたらす $5 つ$ の視点 -. 東京 : 医学書院; 2016. 